\title{
Nilai-nilai Pendidikan Karakter dalam Muatan Pembelajaran Bahasa Indonesia di Kelas III SDS Harapan Jakarta
}

\author{
Ronald Felix Yanuar \\ Universitas Negeri Yogyakarta \\ ronalvincent@gmail.com \\ Theresia Niken Dwi Utami Putri \\ Universitas Negeri Yogyakarta \\ theresianiken24@gmail.com
}

DOI:10.35719/educare.v2i2.74

\begin{abstract}
This research was carried out at SDS Harapan Jakarta. This research aims to unravel the implementation of character education's values through thematic subject, specifically on Indonesian Language Content. This research uses qualitative descriptive approach to gather research data deeply and thoroughly regarding character education's value. Data collection was done using interviews, observation, and documentation. Miles and Huberman method was used to analyze data collected with the process of data collection, condensation, data display, and data verification. Triangulation was used to verify the validity of the data. The result of this study revealed that 1) The implementation of character education values in the content of Indonesian Language learning in Class 3 is implemented through reading and writing activities that prioritize the five main values in education according to the Minister of Education and Culture. 2) There are still less-effective efforts to achieve learning objectives. 3) There is still a lack of learning innovations carried out to achieve learning goals. 4) No lesson plans that are not made routinely as a means of evaluating learning. 5) There is still a need for improvement in the application of character education in Indonesian content that is linked to students' real experiences, both through online and offline learning.
\end{abstract}

Keywords: Character Education; Primary School; Thematic Learning; Indonesian Language Content 


\begin{abstract}
Abstrak
Penelitian ini dilaksanakan di SDS Harapan Jakarta. Penelitian ini bertujuan untuk mengungkap implementasi nilai-nilai pendidikan karakter melalui mata pelajaran tematik, khususnya pada muatan bahasa Indonesia. Penelitian ini menggunakan pendekatan deskriptif kualitatif untuk mengumpulkan data penelitian secara mendalam dan menyeluruh mengenai nilai pendidikan karakter. Pengumpulan data dilakukan dengan wawancara, observasi, dan dokumentasi. Metode Miles dan Huberman digunakan untuk menganalisis data yang dikumpulkan dengan proses pengumpulan data, kondensasi, tampilan data, dan verifikasi data. Triangulasi digunakan untuk memverifikasi keabsahan data. Hasil penelitian ini mengungkapkan bahwa 1) Implementasi nilai pendidikan karakter dalam muatan pembelajaran Bahasa Indonesia di Kelas 3 diterapkan melalui kegiatan membaca dan menulis yang mengedepankan lima nilai utama dalam pendidikan sesuai Permendikbud. 2) Masih ada upaya-upaya yang kurang efektif untuk mencapai tujuan pembelajaran. 3) Masih kurangnya inovasi pembelajaran yang dilakukan untuk mencapai tujuan pembelajaran. 4) Tidak ada RPP yang tidak dibuat secara rutin sebagai sarana evaluasi pembelajaran. 5) Masih perlu adanya perbaikan penerapan pendidikan karakter konten bahasa Indonesia yang dikaitkan dengan pengalaman nyata peserta didik, baik melalui pembelajaran online maupun offline.
\end{abstract}

\title{
Kata Kunci: Pendidikan Karakter; Sekolah Dasar; Pembelajaran Tematik; Muatan Bahasa Indonesia
}

\section{PENDAHULUAN}

Setiap negara di dunia ini memiliki cita-cita untuk memiliki kualtias sumber daya manusia yang berkualitas. Cita-cita tersebut dapat diwujudkan melalui proses pendidikan yang dijalankan dengan tepat. Undang-undang Republik Indonesia Nomor 20 Tahun 2003 menekankan bahwa pendidikan merupakan upaya secara sadar dan terencana dengan tujuan menciptakan suasana dan proses pembelajaran dengan harapan dapat membantu peserta didik untuk mengembangkan kemampuanya dari sisi spiritual, pengendalian diri, kecerdasan, kepribadian, akhlak yang baik, serta keterampilanya secara mandiri. ${ }^{1}$ Selain itu, Permendikbud Nomor 37 Tahun 2018 menjelaskan

${ }^{1}$ Presiden Republik Indonesia, Undang-Undang Republik Indonesia Nomor 20 Tahun 2003 Tentang Sistem Pendidikan Nasional. (2003). 
bahwa tujuan kurikulum pendidikan di Indonesia menekankan pada empat kompetensi, yaitu kompetensi sikap spiritual, sikap sosial, pengetahuan, dan keterampilan. ${ }^{2}$ Maka, dapat diketahui bahwa pendidikan memiliki tujuan untuk mengembangkan aspek kognitif, afektif, dan psikomotorik peserta didik secara mandiri. Ketiga aspek ini perlu ditanamkan dan dikembangkan dalam diri peserta didik melalui pembelajaran di kelas. Aspek kognitif menekankan pada pengetahuan akademis siswa, aspek afektif menekankan pada moral dan karakter siswa, sedangkan aspek psikomotorik menekankan pada keterampilan siswa. ${ }^{3}$

Lickona menjelaskan bahwa pendidikan sejatinya memiliki dua tujuan besar, yaitu mewujudkan manusia yang cerdas dan memiliki akhlak yang baik. ${ }^{4}$ Salah satu upaya yang dilakukan oleh sekolah untuk dapat mewujudkan peserta didikyang memiliki akhlak yang baik adalah melalui penguatan pendidikan karakter. Karakter yang baik pada dasarnya memiliki arti sebagai perilaku hidup yang baik. Terdapat tiga komponen utama dalam karakter yang baik, yaitu pengetahuan moral, perasaan moral, dan tindakan moral. ${ }^{5}$ Tiga komponen ini sejalan dengan prinsip pendidikan di Indonesia yang berusaha mengembangkan aspek kognitif, afektif, dan psikomotorik peserta didik. Sehingga dapat dilihat bahwa di dalam pengembangan aspek afektif peserta didik, terdapat komponen lagi yang serupa dengan aspekaspek pendidikan. Ketiga komponen karakter yang baik ini saling berhubungan dan tidak dapat dipisahkan satu sama lain. ${ }^{6}$ Peserta didik yang memiliki pengetahuan moral yang baik akan cenderung melakukan tindakan

${ }^{2}$ Kemendikbud, Permendikbud RI Nomor 37 tahun 2018 tentang Perubahan atas Peraturan Menteri Pendidikan dan Kebudayaan Nomor 24 tahun 2016 tentang Kompetensi Inti dan Kompetensi Dasar Pelajaran pada Kurikulum 2013 pada Pendidikan Dasar dan Pendidikan Menengah. JDIH Kemendikbud, 2025, 1-527.”(2018).

${ }^{3}$ Muhammad Basyar, Peta Konsep Rana Kognitif, Afektif dan Psikomotorik, (Universitas Muhammadiyah Sidoarjo, 2021).

${ }^{4}$ Lickona, Thomas, Character matters: How to help our children develop good judgment, integrity, and other essential virtues, (Simon and Schuster, 2004), 19.

${ }^{5}$ Lickona, Thomas, Character Matters, 74-77.

${ }^{6}$ Lickona, Thomas, Character Matters, 4, 90. 
moral yang baik atas dasar perasaan moral yang dimilikinya sebagai motivasi.

Saat ini, permasalahan mengenai karakter masih sering dijumpai dalam kehidupan pendidikan di Indonesia. Peserta didik yang tidak datang ke sekolah tepat waktu, berkata kotor, tidak berseragam, melakukan kekerasan fisik ataupun verbal dengan alasan bercanda, atau suka berbohong merupakan contoh perilaku peserta didik dengan karakter yang kurang baik. Permasalahan-permasalahan ini apabila dibiarkan dapat mendorong peserta didik untuk terbiasa melakukan perilaku yang buruk dan tidak mencerminkan karakter yang baik bahkan dapat terbawa hingga peserta didik tersebut dewasa. Tindakan kriminal juga dapat banyak timbul apabila generasi penerus bangsa tidak memiliki karakter yang baik. Untuk dapat mencegah hal ini terjadi, pendidikan karakter perlu ditanamkan dengan baik sejak dini, secara khusus di bangku sekolah dasar.

Pada tingkat sekolah dasar, peserta didik berada pada tahapan perkembangan moral yaitu: pra-konvensional 1, pra-konvensional 2, dan konvensional 3 sebagaimana dalam teori Kohlberg dengan persebaran yang tidak merata, peserta didik pada suatu kelas dapat berada pada tahapan yang lebih rendah atau lebih tinggi dari teman-teman sebayanya. Pada ketiga tahapan ini, peserta didik bergerak dari sudut pandang melakukan sesuatu karena takut akan hukuman menuju kemampuan untuk dapat berperan dalam kehidupan sosial dengan berperilaku baik. ${ }^{7}$ Untuk dapat mengembangkan pendidikan karakter dengan baik, diperlukan desain atau perencanaan yang matang melalui kurikulum yang diterapkan dalam sistem pendidikan.

Kurikulum yang diterapkan dalam pendidikan di Indonesia pada saat ini adalah kurikulum 2013. Pada kurikulum ini, penerapan pendidikan

${ }^{7}$ Enung Hasanah, Perkembangan Moral Peserta didikSekolah Dasar Berdasarkan Teori Kohlberg, JIPSINDO, Jurnal Pendidikan Ilmu Pengetahuan Sosial Indonesia 6, No. 2 (2019): 131-145. 
karakter dilakukan melalui setiap mata pelajaran yang diajarkan di kelas, kegiatan berbasis karakter seperti adiwiyata, serta kegiatan diluar pembelajaran seperti kegiatan keagamaan dan ekstrakulikuler lainya. ${ }^{8}$ Terdapat 18 nilai karakter yang berusaha dicapai melalui pendidikan di Indonesia. Nilai-nilai tersebut diantaranya: 1) religius, 2) toleransi, 3) jujur, 4) kreatif, 5) mandiri, 6) disiplin, 7) komunikatif, 9) kerja keras, 10) rasa ingin tahu, 11) menghargai prestasi, 12) gemar membaca, 13) cinta tanah air, 14) semangat kebangsaan, 15) peduli lingkungan, 16) cinta damai, 17) peduli sosial, dan 18) tanggung jawab. ${ }^{9}$ Dari 18 nilai ini, terdapat lima nilai utama karakter prioritas dalam penguatan pendidikan karakter, yaitu religius, nasionalis, integritas, gotong royong, dan mandiri. ${ }^{10}$ Religius mencerminkan sikap peserta didik terhadap iman yang diyakininya atas Tuhan Yang Maha Esa, nasionalis mengandung arti sikap peserta didik menjunjung tinggi kepentingan bangsa dan negara, integritas memiliki arti menjadikan diri sendiri dapat dipercaya oleh orang lain, gotong royong memiliki arti tindakan pemecahan masalah secara bersama, serta mandiri mengandung arti tidak bergantung dengan orang lain dan dapat dengan semangat meraih mimpi.

Kelima nilai penting tersebut ditanamkan dan dikembangkan melalui semua mata pelajaran secara khusus dalam tematik dan pendidikan agama pada jenjang pendidikan sekolah dasar. ${ }^{11}$ Salah satu muatan dalam mata pelajaran tematik adalah Bahasa Indonesia. Muatan Bahasa Indonesia terdiri atas kompetensi dan ruang lingkup materi. Pada kompetensi, peserta didik

${ }^{8}$ Yusuf, Muhammad, Mahyudin Ritonga, and Mursal Mursal, Implementasi Karakter Disiplin dalam Kurikulum 2013 Pada Bidang Studi PAI di SMA Islam Terpadu Darul Hikmah, Jurnal Tarbiyatuna 11, No. 1 (2020). 49-60.

${ }^{9}$ Iswantiningtyas, Veny, and Widi Wulansari, Pentingnya Penilaian Pendidikan Karakter Anak Usia Dini, Proceedings of the ICECRS 1, no. 3 (2018).

${ }^{10}$ Khairani, Dinia, and Elpri Darta Putra. Analisis Implementasi Lima Nilai Karakter Pendidikan pada Kegiatan Pembelajaran di Sekolah Dasar. Jurnal Basicedu 5, no. 4 (2021): 2247-2255.

${ }^{11}$ Wijanarti, Wilis, I. Nyoman Sudana Degeng, and Sri Untari. Problematika Pengintegrasian Penguatan Pendidikan Karakter Pada Pembelajaran Tematik. Jurnal Pendidikan: Teori, Penelitian, dan Pengembangan 4, no. 3 (2019): 393-398. 
diajarkan untuk memiliki kepedulian, rasa percaya diri, kedisiplinan, dan tanggung jawab dalam pemanfaatan bahasa Indonesia, mengenal konteks budaya dan konteks sosial, satuan kebahasaan, serta unsur paralinguistik dalam penyajian teks, mengenal bentuk dan ciri teks deskriptif serta teks laporan sederhana, menyajikan secara lisan dan tulis berbagai teks sederhana dengan ruang lingkup materi yaitu bentuk dan ciri teks faktual (deskriptif, petunjuk/arahan, laporan sederhana), teks tanggapan (ucapan terima kasih, permintaan maaf, diagram/tabel), teks cerita (narasi sederhana, puisi) teks cerita non naratif (cerita diri/personal, buku harian), konteks budaya, norma, serta konteks sosial yang melatarbelakangi lahirnya jenis teks, para linguistik (lafal, kelantangan, intonasi, tempo, gestur, dan mimik), dan satuan bahasa pembentuk teks: kalimat sederhana dua kata pola SP. ${ }^{12}$

Dengan kompetensi yang sama, ruang lingkup materi yang diajarkan antara lain bentuk dan ciri teks genre faktual (teks laporan informatif hasil observasi, teks arahan/petunjuk, teks instruksi, teks surat tanggapan pribadi), genre cerita (cerita petualangan, genre tanggapan, teks dongeng, teks permainan/dolanan daerah (teks wawancara, ulasan buku). Konteks budaya, norma, serta konteks sosial yang melatarbelakangi lahirnya jenis teks, satuan bahasa pembentuk teks: kalimat sederhana pola SPO dan SPOK, kata, dan kelompok kata dan penanda kebahasaan dalam teks. ${ }^{13} \mathrm{Hal}$ ini menunjukan bahwa muatan bahasa Indonesia dapat mendukung pengembangan karakter peserta didikmelalui kompetensi dan materi yang dikandungnya dalam tingkatan pendidikan sekolah dasar.

Berdasarkan alasan tersebut, penulis melakukan penelitian mengenai implementasi nilai pendidikan karakter dalam muatan pembelajaran bahasa Indonesia di kelas 3 SDS Harapan Jakarta Barat. Penelitian ini diharapkan dapat memberikan evaluasi bagi penerapan nilai pendidikan karakter agar

\footnotetext{
${ }^{12}$ Kemendikbud. Permendikbud RI Nomor 37 tahun 2018 tentang Perubahan atas Peraturan Menteri Pendidikan dan Kebudayaan Nomor 24 tahun 2016, 1-527.

${ }^{13}$ Kemendikbud. Permendikbud RI Nomor 37 tahun 2018 tentang Perubahan atas Peraturan Menteri Pendidikan dan Kebudayaan Nomor 24 tahun 2016. 1-527.
} 
dapat dikembangkan secara menyeluruh melalui perbaikan dan rekomendasi yang dihasilkan melalui penelitian ini. Sekolah-sekolah lain dapat menerapkan rekomendasi yang dihasilkan dari penelitian ini melalui resonansi dari SDS Harapan Jakarta Barat apabila memiliki kesamaan dari segi pengalaman maupun kondisi sekolah dan pembelajaran. Penelitian ini juga diharapkan dapat mengevaluasi dan memperbaiki kualitas pendidikan karakter secara khusus dalam pembelajaran tematik muatan Bahasa Indonesia.

\section{METODE PENELITIAN}

Penelitian ini menggunakan pendekatan kualitatif deskriptif. Penelitian yang menggunakan pendekatan kualitatif deskriptif berusaha menggali data secara mendalam atas suatu fenomena untuk kemudian dihasilkan data yang berupa deskripsi yang detail dalam bentuk kata-kata. ${ }^{14}$ Lokasi penelitian ini adalah SDS Harapan Jakarta Barat. SDS Harapan terletak di Jalan K.S Tubun 1/13, Kota Bambu Utara, Kecamatan Pal Merah, Jakarta Barat, DKI Jakarta dengan kode pos 11480. Terdapat enam peserta didik yang berada di bangku kelas 3 di sekolah ini, hal ini menunjukan bahwa skala guru dibanding peserta didik di sekolah ini kecil. Penelitian ini berfokus pada kelas 3 SD secara purposif. Teknik pengumpulan data yang digunakan dalam penelitian ini adalah wawancara dengan guru kelas, observasi pembelajaran, dan dokumentasi melalui RPP yang dibuat oleh guru. Keabsahan data dalam penelitian ini dilakukan dengan teknik triangulasi teknik dan waktu. Teknik analisis data yang digunakan adalah dengan teori Miles dan Huberman, yaitu dengan proses reduksi data, penyajian data, dan penarikan kesimpulan. ${ }^{15}$

\footnotetext{
${ }^{14}$ Lexy J Moleong, Metodologi Penelitian Kualitatif, (Bandung: Remaja Rosdakarya, 2019), 4

${ }^{15}$ Miles and Hubberman, Qualitative Data Analysis, (United States of America: Arizona State University, 2014), 8-10.
} 


\section{HASIL DAN PEMBAHASAN TEMUAN \\ HASIL TEMUAN}

Berdasarkan hasil wawancara yang dilakukan dengan guru kelas 3 yang memiliki pengalaman mengajar selama empat tahun, dapat diketahui bahwa guru memahami pendidikan karakter sebagai pendidikan yang berpusat pada perilaku peserta didik. Guru menganggap pendidikan karakter penting dilaksanakan di kelas sebagai sarana pembentukan karakter peserta didik yang dipandang utama di sekolah. Pembelajaran tematik dengan muatan bahasa Indonesia dianggap penting oleh guru karena muatan tersebut menjadi awal terbentuknya kemampuan membaca peserta didikdan kemampuan berkomunikasi dengan bahasa yang baik dan benar.

Cara guru mengajarkan kedisiplinan kepada peserta didik ialah dengan membuat aturan dan konsekuensi bagi peserta didik yang melanggar aturan. Aturan tersebut juga dibuat untuk dipatuhi peserta didik dan memberikan rasa keteraturan pada saat kegiatan belajar mengajar berlangsung. Sedangkan dalam mengajarkan sifat dapat dipercaya pada peserta didik adalah dengan guru yang memberikan informasi yang sesuai dengan kenyataan yang ada dan apa yang telah terjadi. Guru sebisa mungkin selalu berkata jujur karena itu mencerminkan citra guru yang mudah dipercaya oleh peserta didik. Jika guru sudah mencontohkan untuk berkata jujur, maka peserta didik juga pasti menirunya. Dengan terciptanya rasa dapat dipercaya atas satu sama lain, antara guru dan siswa, maka dalam bertutur kata dan bertingkah laku akan menjadi lebih berani.

Selain sifat disiplin, sifat religius juga berperan penting dalam perkembangan karakter siswa. Untuk mengajarkan sifat tersebut, maka guru mengajarkan peserta didik untuk membaca doa sebelum dan sesudah belajar. Selain itu, guru mengingatkan peserta didik untuk shalat secara berjamaah bersama keluarga di rumah secara teratur dan disiplin. Guru selalu mengingatkan peserta didik untuk melakukan kegiatan Tadarus setiap sebelum pembelajaran dimulai. Sebagai peserta didiksudah selayaknya 
untuk mengenal dan menerapkan nilai-nilai budaya dan rasa cinta tanah air dalam pembelajaran. Guru tidak lupa untuk mengajarkan lagu daerah kesenian serta memberikan materi kesenian daerah yang masih berhubungan dengan pembelajaran.

Para peserta didik akan mengalami tumbuh hingga dewasa, maka dari itu sikap dan rasa kemandirian sudah sepatutnya ditanamkan di kehidupan peserta didik meskipun baru di fase sekolah dasar. Dalam mengajarkan kemandirian kepada peserta didik di kelas, baik kelas online maupun offline, guru memberikan tugas dengan mencari jawaban di dalam buku tersebut. Kemudian, melakukan kegiatan yang melatih rasa mandiri seperti belajar sendiri dan membantu membersihkan rumah. Negara Indonesia dikenal dengan negara yang gemar bergotong royong, agar julukan itu terus melekat selamanya, maka pada peserta didik SD harus ditanamkan sikap bergotong. Cara guru dalam menumbuhkan sikap gotong royong tersebut yaitu dengan mengajarkan sifat bekerja sama dalam kegiatan kerja bakti baik di lingkungan sekolah. Dalam kegiatan kerja bakti, guru mengajarkan kerja sama dengan pembagian tugas dan tanggung jawab.

Melalui observasi pembelajaran yang dilaksanakan masih secara terbatas melalui metode daring (online) melalui aplikasi WhatsApp, dapat dilihat bahwa pembelajaran yang dilaksanakan secara tematik dalam muatan bahasa Indonesia di sekolah ini menekankan pada kemampuan peserta didik dalam membaca bacaan yang dikirim oleh guru. Kegiatan pembelajaran pada sub tema 1: Aneka Benda di Sekitarku dan subtema 2: Manfaat Hewan bagi Kehidupan Manusia dilaksanakan dengan latihan membaca dan mengerjakan soal yang terdapat dalam buku paket peserta didik keluaran Kemendikbud.

Guru meminta peserta didik untuk merekam kegiatan membaca yang dilakukan di rumah, kemudian dikirim kepada guru melalui pesan group di WhatsApp. Teks yang dibaca pada hari ini berjudul "Ayam Jago Baru". Dalam teks ini, diceritakan mengenai seekor ayam jago yang baru saja 
pindah dari kota menuju suatu dusun. Nilai yang terdapat dalam cerita ini adalah tetap fokus dalam melakukan pekerjaan. Pembelajaran pada subtema 1 dan 2 ini dilaksanakan pada tanggal 23 Agustus 2021, dimulai pukul 6:44 WIB, dan dihadiri oleh tiga orang peserta didikyang aktif dari keseluruhan enam orang peserta didik.

Pada tanggal 25 Agustus 2021, pembelajaran dilaksanakan dengan mempelajari tema 2 dan tema 4. Kegiatan pembelajaran masih sama seperti pada tanggal 23 Agustus 2021, peserta didik membaca teks yang terdapat dalam buku paket tematik dan mengerjakan soal-soal yang terdapat di bawah bacaan tersebut. Peserta didik juga masih diminta untuk merekam proses mereka dalam membaca teks yang diberikan. Teks yang dibaca pada hari itu berjudul "Pergi ke Taman Bunga". Pembelajaran pada tanggal 1 September 2021, tema 2 dan tema 4 masih menjadi bahan pembelajaran. Kegiatan pembelajaran sudah dilaksanakan secara tatap muka atau luring (offline) dengan kegiatan utama membaca teks bacaan dan mengerjakan soal dengan tambahan video pembelajaran yang ditampilkan. Pada saat pembelajaran, dapat dilihat bahwa masih ada beberapa peserta didik yang belum dapat membaca dan menulis dengan lancar. Hal ini membuat fokus kegiatan pembelajaran pada hari tersebut menjadi bertambah dengan adanya kegiatan mengeja dan menulis untuk menguatkan kemampuan peserta didik dalam membaca dan menulis dasar.

Untuk materi yang diajarkan kepada peserta didik kelas 3 pada hari Rabu tanggal 8 September 2021 adalah soal tentang pemberian saran. Terdapat empat soal isian panjang, peserta didik diminta untuk memberikan saran sesuai masalah yang ada, misalnya Udin minta dibelikan baju baru. Di lemari, baju Udin masih banyak dan masih bagus, lalu peserta didikbisa menjawab soal dengan memberikan saran atas masalah Udin. Pada soal tersebut juga tertera contoh kalimat saran. Pada tanggal 13 September 2021, peserta didik diminta menjawab pertanyaan mengenai musyawarah dan 
memberikan pendapat. Soal ini terdiri dari lima pertanyaan dengan jenis isian panjang.

Tema 1 dan tema 2 masih menjadi bahan pembelajaran untuk peserta didik kelas 3 di SDS Harapan. Pada tanggal 22 September 2021 masih melaksanakan pembelajaran secara daring (online) melalui Whatsapp Group. Nasihat dan perintah yang diajarkan kepada peserta didik. Materi ini diajarkan dalam bentuk mengerjakan soal sebanyak sepuluh nomor. Setelah itu tersedia bacaan untuk para peserta didikdengan judul "Rahasia Anak Pintar”. Inti dari teks ini adalah rahasia anak pintar yaitu selalu rajin belajar, banyak berlatih, dan memiliki sifat tidak mudah menyerah. Materi ini merupakan materi yang diajarkan sebelum para peserta didikmelaksanakan Penilaian Tengah Semester (PTS) yang akan dilakukan di sekolah secara tatap muka.

Sedangkan melalui Rencana Pelaksanaan Pembelajaran (RPP), dapat dilihat bahwa guru tidak secara rutin membuat RPP sebagai landasan pelaksanaan pembelajaran. Muatan bahasa Indonesia yang terdapat dalam RPP adalah mengenai kalimat saran pada Kompetensi Dasar (KD) 3.5 mencermati ungkapan kalimat saran, masukan, dan penyelesaian masalah (sederhana) dalam teks tulis dan KD 4.5 memeragakan ungkapan atau kalimat saran, masukan, dan penyelesaian masalah (sederhana) sebagai bentuk ungkapan diri menggunakan kosakata baku dan kalimat efektif yang dibuat sendiri. Tujuan pembelajaran yang dibuat oleh guru tidak sesuai dengan KD dan tidak dijumpai adanya indikator pembelajaran. Dalam bagian kegiatan pembelajaran, guru membuat dua macam kegiatan. Kegiatan yang pertama merupakan kegiatan dengan mengamati video pembelajaran mengenai pecahan sederhana dan kalimat saran. Sedangkan pada kegiatan kedua merupakan kegiatan membaca teks dan pola irama. Dalam lampiran bahasa Indonesia, guru melampirkan teks cerita yang berjudul "Kasih Sayang di Rumah". Teks ini menceritakan mengenai kehidupan manusia yang tidak dapat hidup sendiri dan memerlukan orang 
lain, terutama dalam keluarga. Nilai penting dalam cerita ini adalah untuk saling menyayangi orang lain, terutama anggota keluarga.

\section{PEMBAHASAN TEMUAN}

Pendidikan karakter merupakan pendidikan yang berpusat pada perilaku siswa. Definisi ini masih terlalu luas dan abstrak. Lickona menjelaskan bahwa pendidikan karakter merupakan upaya menumbuhkan dan mengembangkan kemampuan peserta didikuntuk dapat mengerti, menyukai, dan melakukan suatu tindakan berdasarkan nilai etis dan etika. Proses ini dikembangkan kepada peserta didik melalui sekolah, keluarga, dan masyarakat. ${ }^{16}$

Pendapat guru mengenai pendidikan karakter yang dipandang sebagai pusat dalam kehidupan di sekolah sudah sesuai dengan penjelasan Lickona tersebut. Dalam muatan bahasa Indonesia, guru memandang bahwa muatan tersebut penting diterapkan di sekolah sebagai sarana pembentukan dan pengembangan kemampuan membaca dan berkomunikasi yang menjadi dasar dari pembelajaran-pembelajaran selanjutnya di kelas yang lebih tinggi. Pandangan ini yang mendukung guru untuk mengutamakan kegiatan membaca dalam setiap pembelajaran bahasa Indonesia yang dilaksanakan baik secara daring maupun luring.

Penanaman sikap disiplin termasuk ke dalam nilai besar integritas dalam pendidikan karakter di Indonesia. Untuk menanamkan nilai kedisiplinan, guru memanfaatkan peraturan dan konsekuensi bagi peserta didik. Peraturan dan konsekuensi serta penghargaan kepada peserta didik untuk menerapkan nilai kedisiplinan akan dapat berjalan efektif apabila peserta didikturut serta dalam penyusunan peraturan sehingga peserta didik mengerti mengapa aturan tersebut dibuat dan mengapa konsekuensi tersebut dapat memberikan manfaat kepada peserta didik. ${ }^{17}$ Namun, guru tidak terlihat memberikan kesempatan kepada peserta didik untuk berpartisipasi

\footnotetext{
${ }^{16}$ Lickona, Thomas, Character Matters, 19.

${ }^{17}$ Lickona, Thomas. Character Matters: 19.
} 
menyusun peraturan yang diterapkan di kelas, sehingga peserta didik kurang mendapatkan esensi dari pentingnya peraturan tersebut perlu dipatuhi. Hal ini dapat diperbaiki dengan membahas peraturan yang sudah dibuat sebagai bahan atau media belajar di kelas dalam bentuk cerita yang ditanamkan dalam muatan bahasa Indonesia, sehingga penerapan pendidikan karakter kedisiplinan dapat terintegrasikan dengan kurikulum.

Karakter dapat dipercaya juga termasuk ke dalam nilai besar integritas. Dalam menerapkan pembelajaran yang mendorong karakter ini, guru memberikan informasi sesuai kenyataan yang terjadi serta memberi teladan bagi siswa. Namun, upaya guru dalam menerapkan karakter ini kurang dapat terlihat dalam muatan bahasa Indonesia dan interaksi seharihari dalam pembelajaran di kelas. Dalam observasi, dapat terlihat bahwa guru belum menanamkan nilai ini dalam kegiatan kurikuler, termasuk pembelajaran tematik muatan bahasa Indonesia. Nilai dapat dipercaya dalam muatan bahasa Indonesia dapat ditanamkan melalui cerita atau dongeng, salah satunya adalah dongeng Si Kancil yang kaya akan nilai ini. Untuk dapat meningkatkan kualitas pembelajaran di kelas yang menanamkan nilai karakter dapat dipercaya, guru dapat mencari berbagai referensi cerita atau dongeng yang mengandung nilai tersebut untuk dibaca dan dianalisis bersama peserta didikdalam pembelajaran di kelas.

Nilai lainya yang terdapat dalam upaya pengembangan pendidikan karakter Indonesia adalah religius. Dalam pembelajaran, guru menyatakan bahwa guru selalu membuka dan menutup pembelajaran dengan berdoa serta melaksanakan salat berjamaah dan tadarus bagi peserta didikdan guru yang sudah dapat berangkat ke sekolah. Guru juga menyatakan bahwa peserta didikselalu diingatkan untuk melaksanakan ibadah secara mandiri dan tepat waktu di rumah, meskipun hal ini kurang terlihat dari observasi yang dilakukan. Upaya guru dalam menanamkan nilai religius kepada peserta didik sudah baik apabila dikaitkan dengan situasi pandemi yang membatasi kegiatan ibadah secara berjamaah. 
Sikap nasionalisme ditanamkan melalui lagu daerah yang dinyayikan sebelum dimulainya pembelajaran serta kesenian daerah yang ditanamkan dalam pembelajaran. Upaya guru dalam mengembangkan nilai nasionalisme sudah terlihat adanya integrasi dengan kurikulum melalui kegiatan kurikuler. Untuk mengembangkan kualitas pengembangan nilai ini, dapat dilakukan dengan menanamkan rasa nasionalisme dalam muatan bahasa Indonesia. Guru perlu secara konsisten menggunakan bahasa Indonesia yang baku dan benar dalam setiap interaksi dengan siswa, yang mana kurang terlihat dari observasi yang dilakukan. Selain itu guru dapat mengenalkan budaya-budaya daerah melalui teks informasi yang dapat dibaca oleh peserta didik sebagai media pembelajaran bahasa Indonesia. Peserta didikjuga dapat dilatih untuk memiliki rasa nasionalisme dengan mencoba menuliskan sila-sila Pancasila agar dapat dihafalkan secara mandiri.

Kemandirian sendiri juga dipandang penting oleh guru dalam pembelajaran. Nilai ini dikembangkan melalui tugas-tugas yang diberikan oleh guru, yang mana jawaban dari tugas tersebut terdapat dalam buku sehingga peserta didik perlu untuk membuka bukunya untuk dapat menemukan jawaban tersebut. Dalam muatan bahasa Indonesia, guru tidak terlihat memberikan kegiatan serupa dalam pembelajaran, sehingga upaya penanaman nilai kemandirian dalam materi pembelajaran kurang terlihat. Untuk dapat mengatasi masalah ini, guru dapat memberikan pembelajaran dengan menggunakan teks instruksi untuk melakukan sesuatu, seperti memasak telur atau masakan sederhana lainya yang dapat dilakukan oleh peserta didikselama pembelajaran daring di rumah. Peserta didik dapat mempraktikan langkah-langkah yang terdapat dalam teks untuk kemudian didokumentasikan dan dikirimkan kepada guru. Selain itu, nilai kemandirian dapat dikenalkan kepada peserta didik pada kelas 3 melalui cerita pengalaman yang terdapat dalam buku tema. Peserta didik dapat memetik pesan dan menyimpulkan isi cerita dengan bimbingan guru. Hal ini 
membuat muatan bahasa Indonesia dapat menjadi sarana yang tepat untuk menanamkan nilai ini.

Nilai gotong royong dengan kegiatan kerja bakti di sekolah. Pernyataan guru menjelaskan bahwa upaya penerapan karakter gotong royong berusaha dilakukan oleh guru melalui penanaman sikap kerja sama. Hal ini kurang dapat dilihat melalui pengamatan karena peserta didik lebih banyak mengikuti pembelajaran secara daring, sehingga kegiatan kerja bakti di sekolah kurang mungkin dilakukan. Dalam Kompetensi Dasar (KD) di kelas 3 SD muatan bahasa Indonesia sendiri terdapat berbagai peluang untuk menanamkan nilai ini. Setiap KD yang terdapat dalam muatan bahasa Indonesia sudah mengedepankan keaktifan peserta didikdalam belajar, seperti KD 3.1 yang berbunyi "Menggali informasi tentang konsep perubahan wujud benda dalam kehidupan sehari-hari yang disajikan dalam bentuk lisan, tulis, visual, dan/atau eksplorasi lingkungan"18 Dari sini, dapat dilihat bahwa peserta didik dituntut untuk secara mandiri menggali informasi mengenai perubahan wujud benda dengan membaca teks tulis, informasi lisan, maupun gambar visual, serta eksplorasi lingkungan. Hal ini dapat menjadi sarana bagi guru untuk mengembangkan kualitas pembelajaran, secara khusus pendidikan karakter yang dimuat dalam mata pelajaran tematik muatan bahasa Indonesia.

Pembelajaran dapat terlihat mengedepankan kegiatan membaca dan mengerjakan soal, baik secara daring maupun luring. Cerita yang dibaca terlihat memiliki nilai moral yang baik dan sesuai dengan kelima nilai karakter utama Indonesia. Meskipun belum semua peserta didikterlihat menunjukan sikap disiplin selama pembelajaran, terdapat juga peserta didik yang antusias dan memiliki kedisiplinan yang baik. Kegiatan membaca dan mengerjakan soal yang dilakukan secara daring terlihat kurang menonjolkan nilai gotong royong yang menjadi salah satu nilai utama karakter Indonesia,

${ }^{18}$ Kemendikbud, Permendikbud RI Nomor 37 tahun 2018 tentang Perubahan atas Peraturan Menteri Pendidikan dan Kebudayaan Nomor 24 tahun 2016 5, 1-527 
kebanyakan kegiatan dilakukan secara mandiri oleh setiap peserta didik. Guru terlihat lebih menonjolkan nilai kemandirian kepada peserta didik dalam setiap kegiatan pembelajaranya, hal ini merupakan salah satu dari kelima nilai utama karakter Indonesia. Hal ini dapat menjadikan pembelajaran efektif apabila dilaksanakan dengan bimbingan yang baik dari guru. Namun, guru terlihat kurang mendukung proses belajar peserta didik di rumah.

Nilai-nilai karakter yang terdapat dalam bacaan juga dapat dilihat dengan mudah. Seperti dalam teks "Pergi ke Taman Bunga", dapat terlihat dengan jelas nilai yang berusaha ditanamkan, yaitu menaati peraturan. Nilai menaati peraturan merupakan salah satu cerminan karakter disiplin yang merupakan salah satu bentuk integritas. Namun, peserta didik belum dapat terlihat dapat menemukan atau menyimpulkan nilai yang terdapat dalam cerita ini. Alangkah lebih baik apabila peserta didik dapat diberikan kesempatan untuk mencari nilai dalam cerita secara mandiri dan menunjukan bentuk penerapanya dalam kehidupan sehari-hari peserta didik sehingga pembelajaran yang dilaksanakan dapat lebih konkret.

Kegiatan yang dilakukan secara luring tidak jauh berbeda dengan kegiatan daring, yaitu membaca dan mengerjakan soal untuk muatan bahasa Indonesia. Hal ini menunjukan bahwa guru masih berusaha mengembangkan kemampuan membaca dasar bagi peserta didik dan kemampuan untuk memahami isi bacaan. Namun, peserta didik yang berangkat ke sekolah untuk belajar tatap muka ternyata masih banyak yang belum menguasai kemampuan membaca dan menulis dengan baik, sehingga diperlukan latihan tambahan. Hal ini menunjukan bahwa selama pembelajaran daring, kegiatan membaca yang dilakukan kurang efektif dan kurang dapat melatih kemampuan dasar peserta didikdalam membaca. Untuk dapat mengatasi permasalahan ini, dapat dilakukan pembelajaran tambahan (les khusus) bagi peserta didik yang dirasa kurang dalam aspek membaca dan menulis dasar agar tidak tertinggal dengan teman sebayanya 
dalam mengikuti pembelajaran. Kegiatan pembelajaran luring yang dilakukan juga masih terbatas dan kurang memanfaatkan media yang bervariasi sehingga dapat terbilang monoton. Untuk dapat mengatasi permasalahan ini, guru dapat memanfaatkan berbagai media seperti boneka tangan, gambar bergerak, atau permainan peran untuk mengajarkan materi membaca cerita kepada peserta didik.

Kegiatan pembelajaran daring kembali dilakukan setelah dalam waktu yang singkat diupayakan untuk terlaksananya pembelajaran tatap muka. Bacaan dalam muatan bahasa Indonesia yang digunakan adalah teks yang berjudul "Taman Kota" dan "Memelihara Ikan Hias". Kedua teks ini memiliki nilai moral yang mendorong karakter kemandirian peserta didikyang terlihat dari cara Bondan merawat ikan yang dapat dicontoh oleh peserta didiksecara mandiri di rumah, serta memelihara taman kota dengan membuang sampah pada tempatnya. Hal ini menunjukan bahwa nilai kepedulian terhadap lingkungan, baik itu hewan maupun tumbuhan, juga ditanamkan melalui teks bacaan dalam muatan bahasa Indonesia. Namun, pengalaman pembelajaran tatap muka yang dilakukan secara singkat baiknya dapat digunakan sebagai bahan evaluasi bagi guru untuk mengemas pembelajaran ke depanya, secara khusus mengenai penerapan pendidikan karakter di dalam muatan bahasa Indonesia, yang mana upaya ini belum terlihat secara jelas.

Kegiatan mengerjakan soal mengenai pemberian saran yang dilakukan dapat mendorong peserta didik untuk memiliki rasa keinginan dan kesediaan untuk mendengarkan pendapat teman sebayanya, sehingga dapat mendorong rasa demokratif bagi peserta didik. Namun, untuk dapat menanamkan sikap ini, alangkah lebih baik kegiatan dilengkapi dengan praktik yang mendorong kemampuan berbicara peserta didik dan kreativitasnya dalam memberikan tanggapan atas suatu kejadian. Hal ini dapat menjadi sarana bagi guru untuk melihat kemampuan berbicara peserta didik bisa diobservasi secara daring. Guru dapat meminta peserta didik untuk merekam 
tanggapan atas suatu kejadian yang diberikan, atau melakukan panggilan video untuk dapat melihat kemampuan peserta didikmemberikan saran secara langsung.

Rencana Pelaksanaan Pembelajaran (RPP) yang disusun oleh guru menunjukan bahwa guru tidak secara rutin menyusun RPP dalam setiap pembelajaran. Hal ini menunjukan bahwa pembelajaran yang dilakukan setiap harinya kurang sistematis dan tidak terdokumentasikan. Selayaknya, guru perlu menyusun RPP dalam setiap pembelajaran agar pembelajaran dapat berjalan lebih baik, efektif, sistematis, dan jelas. RPP ini sendiri diperlukan untuk membantu guru dalam proses pembelajaran dan sebagai dokumentasi kegiatan pembelajaran yang dapat digunakan sebagai sarana evaluasi pembelajaran bagi guru. RPP yang disusun oleh guru menunjukan bahwa kegiatan yang dilakukan masih secara daring. Guru tidak terlihat menyusun RPP untuk kegiatan luring yang sudah lama tidak dilakukan di sekolah. Media yang terdapat dalam RPP juga masih terbatas menggunakan WhatsApp saja, padahal dalam kegiatan pembelajaran terdapat video yang dibagikan dari YouTube. Hal ini menunjukan bahwa guru masih perlu menguasai penyusunan RPP secara lebih sistematis, teliti, dan jelas. Untuk dapat mengatasi masalah ini, sekolah dapat melaksanakan pelatihan atau workshop penyusunan RPP bagi guru untuk meningkatkan kualitas guru sebagai tenaga pendidik. Sekolah juga perlu mendorong guru untuk menyusun RPP dalam setiap pembelajaranya agar dapat membantu administrasi sekolah untuk langkah akreditasi. Guru juga masih memerlukan pelatihan dalam menyusun RPP yang mendorong pendidikan karakter dan pembelajaran kurikulum 2013 yang aktif, mandiri, dan kreatif. Metode dan media pembelajaran bagi guru perlu ditingkatkan dengan pelatihanpelatihan dari sekolah seperti pelatihan pemanfaatan teknologi (IT), membuat pembelajaran scientific learning, menyusun pembelajaran dengan pendekatan problem-based learning atau berbasis masalah, serta pengembangan karakter peserta didik. 


\section{SIMPULAN}

Hasil dari penemuan dan penjelasan data dapat menghasilkan kesimpulan, yaitu: 1) Pembelajaran tematik muatan bahasa Indonesia yang dilakukan pada kelas 3 SDS Harapan Jakarta Barat mengupayakan penanaman lima nilai besar karakter Indonesia melalui kegiatan membaca dan menulis. 2) Masih terdapat upaya yang kurang efektif dan kurang sesuai dengan kompetensi dasar yang terdapat dalam muatan bahasa Indonesia. 3) Masih kurangnya inovasi pembelajaran yang dilakukan untuk memberikan pembelajaran yang sesuai dengan konsep merdeka belajar dari kurikulum 2013. 4) Belum adanya upaya improvisasi dan evaluasi dari guru melalui penyusunan RPP yang tidak dibuat secara rutin sebagai sarana evaluasi pembelajaran. 5) Masih diperlukan peningkatan dalam penerapan pendidikan karakter dalam muatan bahasa Indonesia yang dikaitkan dengan pengalaman nyata peserta didik, baik melalui pembelajaran daring maupun luring.

\section{DAFTAR PUSTAKA}

Basyar, Muhammad. Peta Konsep Rana Kognitif, Afektif dan Psikomotorik." Universitas Muhammadiyah Sidoarjo. 2021.

Hasanah, Enung. Perkembangan Moral Peserta didikSekolah Dasar Berdasarkan Teori Kohlberg." JIPSINDO, Jurnal Pendidikan Ilmu Pengetahuan Sosial Indonesia 6, no. 2. 2019.

Iswantiningtyas, Veny, and Widi Wulansari. Pentingnya Penilaian Pendidikan Karakter Anak Usia Dini. Proceedings of the ICECRS 1, no. 3. 2018.

Kemendikbud. Permendikbud RI Nomor 37 tahun 2018 tentang Perubahan atas Peraturan Menteri Pendidikan dan Kebudayaan Nomor 24 tahun 2016 tentang Kompetensi Inti dan Kompetensi Dasar Pelajaran pada Kurikulum 2013 pada Pendidikan Dasar dan Pendidikan Menengah. JDIH Kemendikbud, 2018. 
Khairani, Dinia, and Elpri Darta Putra. "Analisis Implementasi Lima Nilai Karakter Pendidikan pada Kegiatan Pembelajaran di Sekolah Dasar." Jurnal Basicedu 5, no. 4 (2021): 2247-2255.

Moleong Lexy J. Metodologi Penelitian Kualitatif. Bandung: Remaja Rosdakarya, 2019.

Lickona, Thomas. Character Matters: How To Help Our Children Develop Good Judgment, Integrity, And Other Essential Virtues. Simon and Schuster, 2004.

Miles and Hubberman. Qualitative Data Analysis. United States of America: Arizona State University, 2014.

Wijanarti, Wilis, I. Nyoman Sudana Degeng, and Sri Untari. Problematika Pengintegrasian Penguatan Pendidikan Karakter Pada Pembelajaran Tematik. Jurnal Pendidikan: Teori, Penelitian, dan Pengembangan 4, no. 3. 2019.

Yusuf, Muhammad, Mahyudin Ritonga, and Mursal Mursal. Implementasi Karakter Disiplin dalam Kurikulum 2013 Pada Bidang Studi PAI di SMA Islam Terpadu Darul Hikmah. Jurnal Tarbiyatuna 11, no. 1. 2020 . 